http://ejournal.upi.edu/index.php/jaz - e-mail: jurnal_zonasi@upi.edu doi.org/10.31288/jaz.v4i2.31288

\title{
Arsitektur Folding pada Stadion Akuatik Bertaraf Internasional
}

\author{
Article History: \\ First draft received: \\ 13 Januari 2021 \\ Revised: \\ 22 April 2021 \\ Accepted: \\ 4 Juni 2021 \\ First online: \\ 4 Juni 2021 \\ Final proof received: \\ Print: \\ 15 Juni 2021 \\ Online \\ 15 Juni 2021
}

Jurnal Arsitektur ZONASI

is indexed and listed in

several databases:

SINTA 4 (Arjuna)

GARUDA (Garda Rujukan Digital)

Google Scholar

Dimensions

oneSearch

BASE

Member:

Crossref

RJI

APTARI

FJA (Forum Jurna Arsitektur)

IAI

AJPKM

\author{
Reyhan Arief ${ }^{1}$ \\ Wafirul Aqli ${ }^{2}$ \\ 1,2 Jurusan Arsitektur, Fakultas Teknik, Universitas Muhammadiyah Jakarta \\ Jl. Cempaka Putih Tengah 27, RT. 11/RW.5, Cempaka Putih Timur, Kec. Cempaka Putih, \\ Kota Jakarta Pusat, Daerah Khusus Ibukota Jakarta 10510 \\ Email: reyhan.arief88@gmail.com \\ wafirul.aqli@ftumj.ac.id
}

\begin{abstract}
Wide span structure buildings are popular structures, especially in buildings that require column-free space, one of which is sports buildings. The field of water sports, namely swimming, is a sport that is quite popular with Indonesians. The shapes and facades of aquatic buildings are very diverse in order to show beauty and reflect a dynamic and beautiful swimming sport. The beauty of form and building facades is crucial in the world of architecture. Folding architecture is one of the techniques for finding forms in architectural design, by using paper material and transforming a previously dimensionless piece of paper into one dimensional shape. Creativity in transforming paper is an important factor by mixing various processes such as folding, cutting, turning, etc. The architect's imagination in the exploration of this paper formation will create an original, dynamic, creative and innovative form of building design.
\end{abstract}

Keywords: Aquatic, Folding Architecture, Wide Span, and Stadium.

\begin{abstract}
Abstrak: Bangunan struktur bentang lebar merupakan struktur yang populer terutama pada bangunan yang membutuhkan ruang yang bebas kolom salah satunya bangunan olahraga. Bidang olahraga air yaitu renang merupakan bidang olahraga yang cukup digemari masyarakat Indonesia. Bentuk dan fasad bangunan akuatik sangat beragam demi menampilkan keindahan dan mencermikan olahraga renang yang dinamis dan indah. Keindahan bentuk dan fasad bangunan merupakan hal krusial dalam dunia arsitektur. Arsitektur folding merupakan salah satu teknik pencarian bentukan dalam desain arsitektur, dengan mengunakan material kertas dan mentransformasikan selembar kertas yang sebelumnya tidak berdimensi menjadi berdimensi. Kreativitas dalam mentransforsmasikan kertas menjadi faktor penting dengan mencampur berbagai macam proses seperti melipat, memotong, memutar, dll. Imajinasi arsitek dalam eksplorasi bentukan kertas ini akan menciptakan sebuah bentuk desain bangunan yang orisinil, dinamis, kreatif dan inovatif.
\end{abstract}

Kata Kunci: Akuatik, Arsitektur Folding, Bentang Lebar, dan Stadion.

\section{Pendahuluan}

Arsitektur merupakan praktik seni dalam merancang bangunan. (Pallasmaa, 2018) Keterampilan, kreatifitas, ilmu dan pengetahuan sangatlah penting bagi seorang arsitek dalam merancang bangunan. Bangunan yang baik bukan hanya bangunan yang kokoh dan fungsional, namun juga indah dan memiliki nilai estetika tersendiri. (Hujaeri, 2019)

Nilai estetika pada bidang arsitektur, dapat dilihat dari berbagai aspek dengan contoh aspek yang paling mudah dilihat adalah keunikan bentuk bangunan. (Ramli \& Santosa, 2020) Bangunan yang memliki bentuk unik masih menjadi hal yang dispesialisasikan yang berujung meminimalisir keberadaannya. Mencari bentuk unik untuk rancangan bentuk bangunan dibutuhkan konsep yang matang namun juga mudah untuk 
disosialisasikan. Hal ini bertujuan untuk memperkaya bentuk unik dalam bidang arsitektur bukan hanya bentuk luarnya namun keseluruhannya. Arsitektur folding menjadi populer dengan dua alasan yang penting dalam menciptakan desain arsitektur yang inovatif. Kedua alasan tersebut yaitu memiliki struktur arsitektur yang kreatif dengan kemampuan membawa beban yang menguntungkan dan menghasilkan bentuk arsitektur yang estetis dan dapat direalisasikan. (Shen \& Nagai, 2017)

Arsitektur folding merupakan teknik pencarian bentuk menggunakan media kertas. (Taliawo, Tarore, \& Rompas, 2018) Media kertas yang sangat dekat dengan semua kalangan terlebih arsitek. Konsep arsitektur folding mengarahkan arsitek untuk memberikan aksi atau perlakuan terhadap media kertas tersebut. Aksi atau perlakuan tersebut menjadikan selembar kertas menjadi sebuah bentuk unik berdimensi. (Gregory, Supardjo, \& Mandey, 2017) Tidak hanya medianya yang dekat dengan seorang arsitek, namun juga aksi atau perlakuannya yang dekat dengan semua kalangan. Aksi atau perlakuan tersebut merupakan kegiatan yang sudah cukup awam dan sangat luas, mulai dari melipat, menggunting, membuka, menggulung, menggandakan bentuk dan masih banyak lagi.

Aksi atau perlakuan terhadap media kertas yang cukup luas memungkinkan arsitek atau siapapun untuk mengeksplorasi bentuk dalam merangcang bangunan. Tahapan mengolah bentuknya pun dapat dilakukan dengan kemampuan dasar dalam menghasilkan ide kreatif hanya dengan cara dasar melipat dan semacamnya. (Dewi \& Hayyun, 2018) Hal ini akan menjadikan daya kreativitas dan imajinasi arsitek sebagai perancang bentuk sebagai tolak ukur keunikan sebuah bentukan yang dihasilkan. Dari penerapan teknik ini diharapkan timbulnya ide - ide baru yang orisinil dari sebuah bentukan bangunan yang belum ada sebelumnya. Menjadikan proses pencarian bentuk dalam arsitektur lebih dinamis, kreatif dan inovatif.

Dengan tujuan penelitian sebagai bahan pemahaman mengenai proses penerapan konsep arsitektur folding dengan cara yang mudah dimengerti. Hal ini berkaitan dengan rumusan masalah penelitian yang mempertanyakan cara hingga prinsip apa yang perlu dan dapat diterapkan pada karya arsitektur dengan konsep arsitektur folding. Penelitian ini juga diharapkan dapat memperluas eksistensi dari penggunaan konsep arsitektur folding yang mampu memperkaya ide dan bentuk kreatif dalam bidang arsitektur di Indonesia maupun dunia.

\section{Metode Penelitian}

Metode penelitian yang dipilih untuk menyusun laporan penelitian ini diambil demi mengarahkan seluruh langkah penelitian untuk mencapai tujuan dari penelitian ini. Metode deskriptif kualitatif merupakan metode yang tepat untuk digunakan pada penyusunan laporan penelitian ini. Metode yang akan menjabarkan secara luas fakta dan informasi yang didapat di lapangan hingga mngarahkan penulisan kepada hasil berupa kesimpulan. (Muhajjalin \& Satwikasari , 2020) Metode ini akan membantu pencapaian tujuan penelitian yaitu pemahaman dari segala aspek penelitian.

Penelitian dilakukan pada ketiga studi kasus dengan satu tipologi bangunan yang sama. Bangunan bentang lebar dengan fungsi stadion akuatik, menjadi tipologi studi kasus penelitian ini. Ketiga studi kasus tersebut adalah Stadion Akuatik Gelora Bung Karno, London Aquatics Centre, dan Zhejiang HuangLong Aquatics Center.

Ketiga studi kasus tersebut dilakukan pengkajian dengan sebuah pendekatan arsitektur yaitu arsitektur folding. Prinsip arsitektur folding yang menjadi bahan materi penelitian didapati dari dalam buku Folding Architecture tulisan Sophia Vyzoviti. Prinsip arsitektur folding menurut Sophia Vyzovity memiliki empat trasisi daam sebuah proses desain arsitekturnya. Keempat transisi tersebut yaitu, transisi pertama (materi dan fungsi); transisi kedua (algoritma); transisi ketiga (spasial, struktural dan organisasional); dan transisi keempat (prototipe arsitektur).

\section{Hasil dan Pembahasan}

\subsection{Arsitektur Folding}

Pada abad ke-20, terdapat seorang ilmuwan matematika bernama Leibniz yang berpendapat bahwa bentukan alam dapat muncul dari perhitungan matematika. Begitu pula pada tahun 1988, seorang filsuf Perancis yang bernama Gilles Deleuze mengeluarkan buku dengan judul The Fold. HIngga pada akhir abad dua puluh, Peter Eisenmann menjadikan teori konsep arsitektur folding popular dan mulai diminati. (Torondek \& Erdiono, 2017) Pada tahun 1993, Greg Lynn mengeluarkan buku berjudul Folding in Architecture, pada saat itu buku tersebut dijuluki sebagai teori yang hadir tepat pada akhir era milenium. (Mailoor, Siregar, \& Karongkong, 2017) Adapun penjelasan dari seorang pengajar bernama Miguel San Millán ini dituliskan dalam karyanya berjudul Folding City - Unfolded Toy ditahun 2010. (Rahman, 2018) Setelah pengembangan konsep 
arsitektur folding dari berbagai tokoh, Sophia Vyzoviti seorang arsitek, peneliti dan pengajar menerbitkan buku yang berjudul Folding Architecture - Spatial, Structural and Organizational Diagrams. Buku yang berisikan survei mengenai penerapan arsitektur folding pada semua konsep, proyek dan bangunan. Sophia Vyzoviti menjadi salah satu arsitek yang cukup dikenal dalam perkembangan arsitektur folding. (Macarthur, 2019)

Dalam buku Folding Architecture tulisan Sophia Vyzovity (Vyzovity, 2004) dijelaskan bahwa dalam proses mendesain karya arstiktur dengan metode folding terdapat empat fase transisi. Transisi pertama (materi dan fungsi), merupakan perlakuan awal terhadap materi yang digunakan yaitu kertas agar memiliki bentuk bervolume. Hal ini dilakukan melalui proses - proses yang tetap mempertahakan kesatuan, keterikatan dan struktur kertas itu sendiri, proses tersebut dapat berupa melipat, menekan, melipat, merobek, memotong, dan lain sebagainya. Proses tersebut adalah bentuk penerjemahan dari apa yang Deleuze dan Guattari sebut sebagai "mesin abstrak", yang digunakan untuk menjelaskan keberadaan sebuah bentuk dan materi secara tidak terbatas yang dapat diaktualisasikan dalam kondisi tertentu. (Olivier, 2017) Transisi kedua (algoritma), merupakan hasil pemetaan yang didapati pada materi kertas yang merespon proses perlakuan sebelumnya. Hasil dari proses perlakuan terhadap materi yang repetitif memberikan bekas atau respons seperti triangulasi, stress forming, lipatan bersusun, lipatan dalam lipatan, kurva, spiral dan berkelok - kelok. Definisi dari algoritma ini merupakan proses (pada kasus ini merupakan bekas lipatan kertas) yang menghasilkan pemetaan transformasi atau rencana yang terarah. (Hafiludien \& Istiawan, 2018) Selanjutnya ada transisi ketiga (diagram spasial, struktural, dan organisasional), dimana bentukan yang telah didapati akan diwujudkan menjadi sebuah bentuk dengan rencana ruang spasial hingga struktural maupun organisasional. Hal - hal seperti ruang spasial hingga structural sangat krusial karena berkaitan dengan tipologi bangunan hasil dari perlakuan terhadap kertas. (Aisy \& Anisa, 2020) Dari transisi ini akan semakin tergambar realisasi dari sebuah konsep rancangan bangunan, hingga diperjelas pada transisi berikutnya. Transisi keempat (prototipe arsitektur), sebagai pamungkas dari semua proses konseptual merancang desain bangunan ini. Dengan mewujudkan bentukan yang didapat menjadi sebuah wujud digital. Wujud digital ini dapat berupa miniatur atau gambar yang menjelaskan baik ruang, struktur maupun organisasi pada desain tersebut. Prototipe pada arsitektur yang telah disebut sebagai wujud digital disini, menurut Floyd dapat berarti apa saja yang membahas isu yang berkaitan dengan kualitas atau konsep arsitektur sebagai target pencapaiannya. Maka wujud digital disini dapat berarti luas dengan syarat bertujuan untuk menggambarkan konsep yang menjadi target spesifik pada desain arsitekturnya. (Fauri, 2018)

\subsection{Analisis Arsitektur Folding pada Studi Kasus}

\section{Transisi Pertama (Materi dan Fungsi)}

Dapat dilihat pada Gambar 1 di bawah dilihat bahwa lipatan - lipatan pada atap bangunan memiliki variasi kemiringan, hal ini membuktikan adanya score atau perhitungan tiap lipatan. Perhitungan yang digunakan sebagai acuan memiringkan antar lipatan satu dan lainnya. Lalu penerapan aksi fold pun terlihat jelas dari lipatan - lipatan pada atap yang secara kontinu atau berulang menciptakan betukan sebagai pleat. Bentukan akhir pada atap bangunan akuatik Gelora Bung Karno dinamakan pleat atau sebuah bentuk yang didapat dari lipatan - lipatan berulang secara bolak - balik. Aksi - aksi tersebut merupakan transisi pertama pada bentukan atap Stadion Akuatik Gelora Bung Karno.
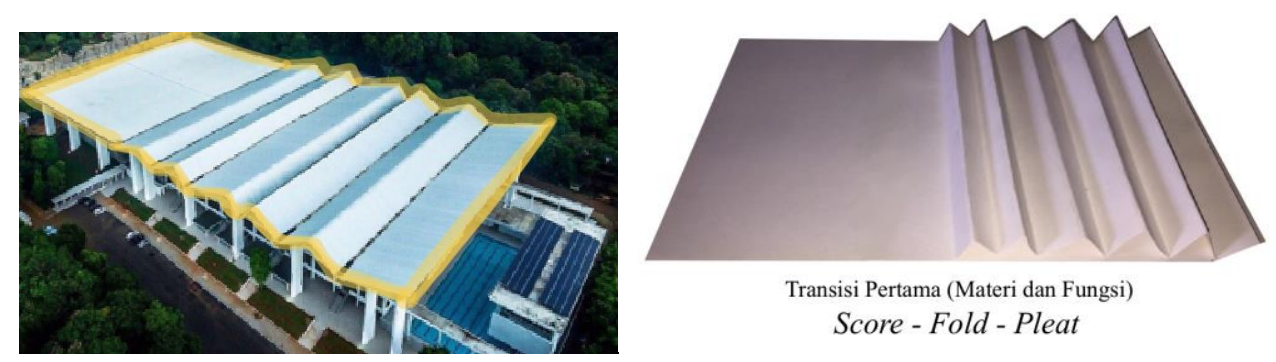

Gambar 1. Transisi Pertama pada Stadion Akuatik Gbk (Sumber: analisis, 2020)

Pada Gambar 2, perlakuan awal dalam pembentukan atap dilakukan dengan pemotongan yang melengkung untuk mendapatkan bentuk seperti oval, lalu potongan tersebut ditarik keatas ( $p u l l$ up) sehingga membuka. Bukaan yang dihasilkan dari pull up pada kertas yang sudah dipotong menyerupai oval tersebut 
akan menjadi celah masuk selembar kertas persegi panjang yang akan membentang dari sisi bukaan yang ada (cross). Pada bagian persegi yang membentang memasuki celah atau bukaan dari kertas oval sebelumnya akan menjadi tribun pada bangunan dan lembar oval sendiri akan menjadi atap utama sebagai atap kolam renang bangunan London Aquatic Centre.
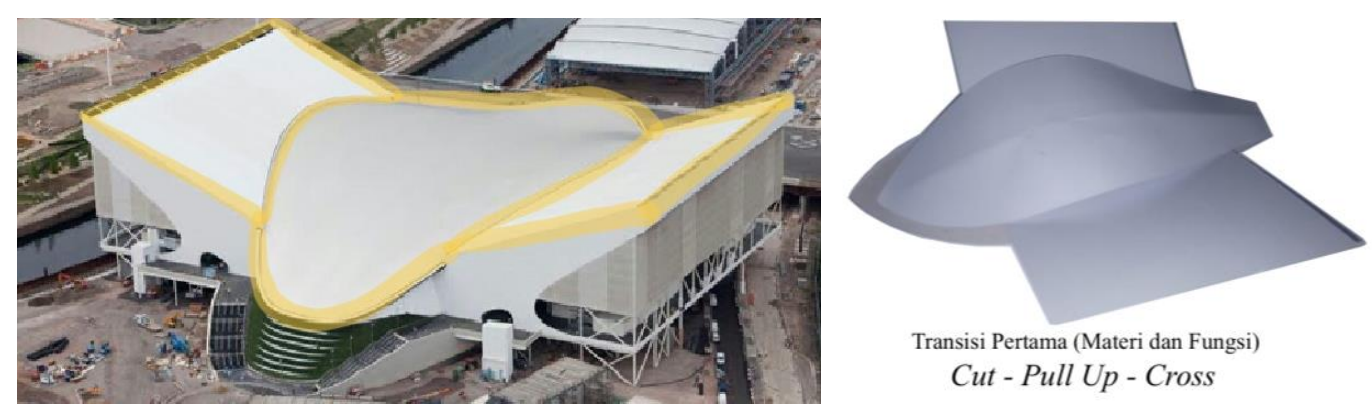

Gambar 2. Transisi Pertama pada London Aquatic Center (Sumber: analisis, 2020)

Transisi pertama pada bangunan Zhejiang Huanglong Aquatics Center terlihat di Gambar 3 di bawah ini. Dapat dilihat aksi rotate dan bend yang dapat dilihat pada bagian tengah menekuk membentuk seperti huruf S. Perlakuan kedua aksi tersebut yang diibaratkan dari selembar kertas dapat menghasilkan bentuk lengkungan seperti huruf $S$ tersebut. Lalu aksi inverse dapat dilihat dari pembentukan lengkungan S paling atas yang membalikkan arah lengkungan di bawahnya secara terbalik atau mengarah berlawanan. Sehingga dapat disimpulkan bentukan bangunan Zhejiang Huanglong pada transisi pertama menggunakan aksi rotatebend-inverse.
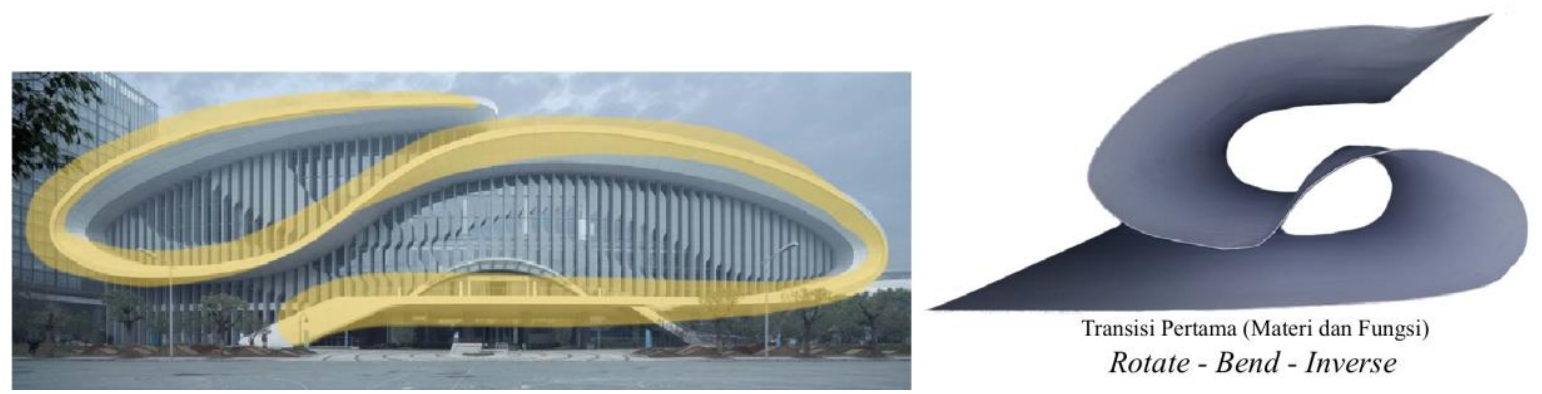

Gambar 3. Transisi Pertama pada Zhejiang Huanglong Aquatics Center (Sumber: analisis, 2020)

\section{Transisi Kedua (Algoritma)}

Dapat dilihat pada Gambar 4 di bawah, transisi kedua dengan hasil mapping berbentuk instructive plan (rencana instruktif). Langkah - langkah bentukan kertas menjadi bentukan diawali dari score (pola bekas lipatan) pada bagian kanan kertas, jarak antar garis pun berbeda - beda menciptakan kedinamisan layaknya air. Kemudian dari score yang didapat dilakukanlah lipatan - lipatan (folding) yang berulang dan jadilah pleat. Pada gambar terlihat perubahan antara sudut lipatan yang diubah menjadi berbeda-beda hingga menciptakan bentuk gelombang yang lebih alami.

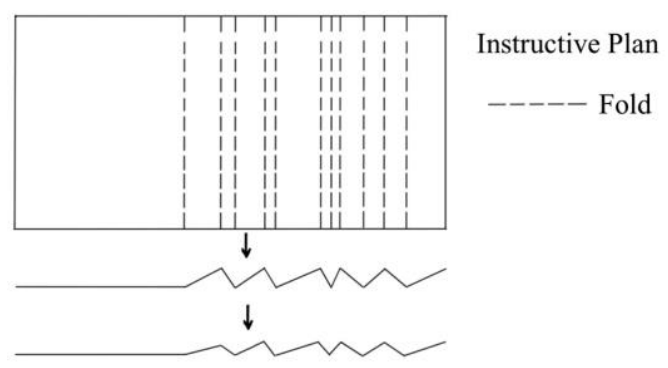

Gambar 4. Transisi Kedua pada Stadion Akuatik Gbk (Sumber: analisis, 2020)

Pada Gambar 5, dapat dilihat pemetaan berupa transformation mapping (pemetaan transformasi). Pada langkah awal pembuatan bentukan ini dilakukan pemotongan atau cutting pada garis putus yang terdapat di 
gambar tersebut. Dari pemotongan tersebut kertas di tarik keatas ( $p u l l$ up). kemudian siapkan kertas dengan bentuk persegi panjang, kertas tersebut dibentangkan melewati celah (crossing) yang didapat dari hasil pull up.

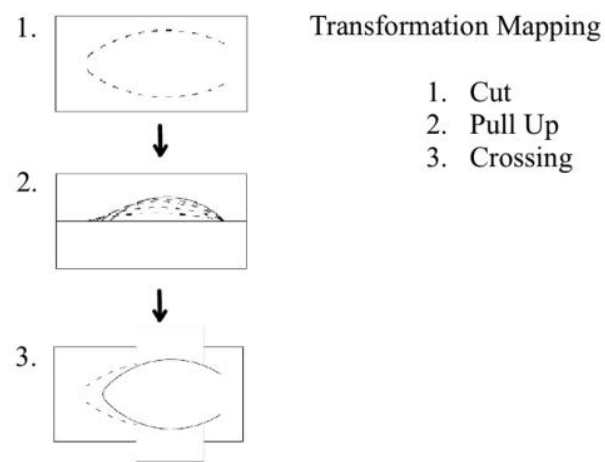

Gambar 5. Transisi Kedua pada London Aquatic Center (Sumber: analisis, 2020)

Transisi kedua pada bangunan Zhejiang Huanglong Aquatics Center terlihat di Gambar 6 di bawah ini. Hasil transformasi pertama, bentukan bangunan ini menggunakan kertas. Dari bentukan tersebut didapati pola aksi melipat yang digunakan yang diawali dari tekukan kedalam rotate menciptakan lengkungan kearah kiri kemudian pada bagian tengah dilakukan aksi bend, langkah terakhir sama seperti langkah pertama dengan melakukan aksi rotate namun secara berlawanan (inverse) menciptakan lengkungan kearah kanan. Seluruh langkah dari aksi melipat ini dipetakan pada secarik kertas dalam bentuk instructive plan (rencana instruktif).

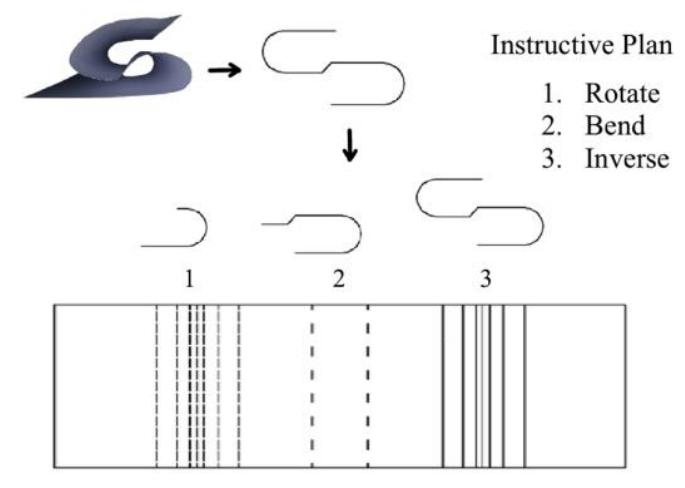

Gambar 6. Transisi Kedua pada Zhejiang Huanglong Aquatics Center (Sumber: analisis, 2020)

\section{Transisi Ketiga (Spasial, Struktural dan Organisasional)}

Dapat dilihat pada Gambar 7 di bawah bahwa ruang spasial yang terbentuk dari transisi ketiga pada bangunan Stadion Akuatik Gelora Bung Karno tercipta dari hanya penambahan dinding saja tanpa teknik melipat apapun. Maka dapat dinyatakan bahwa pada desain Stadion Akuatik Gelora Bung Karno tidak menggunakan konsep folding pada transisi ketiga atau dalam mewujudkan ruang spasialnya.

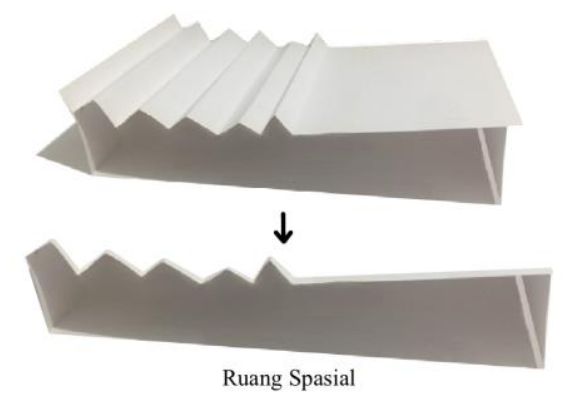

Gambar 7. Transisi Ketiga pada Stadion Akuatik Gbk (Sumber: analisis, 2020) 
Pada Gambar 8, terlihat dua sisi dari desain ruang spasial pada bangunan London Aquatics Centre. Dalam mewujudkan bentuk ruang spasialnya, pada transisi ketiga desain ini dilakukan teknik enclosure oblique ground. Hal ini terlihat pada pembentukkan ruang spasial pada seluruh sisi bangunan dengan memberikan area tetap (enclosure) pada ruang spasial yang terbentuk antara area (enclosure) dengan bentuk transisi sebelumnya. Lalu pada potongan gambar terlihat adanya bentuk-bentuk dinamis yang dibentuk dalam merancang ruang spasial di dalam bangunan, teknik ini dapat dinamakan oblique ground pada teori transisi ketiga menurut Sophia Vyzovity.

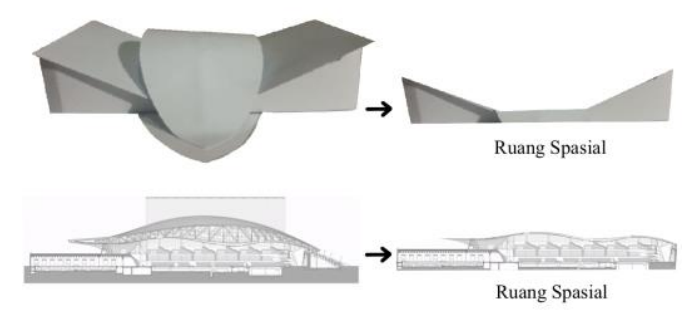

Gambar 8. Transisi Ketiga pada London Aquatic Center (Sumber: analisis, 2020)

Transisi ketiga pada bangunan Zhejiang Huanglong Aquatics Center terlihat di Gambar 9 di bawah ini. Bentuk ruang spasial yang diciptakan dari transisi ketiga. Transisi ketiga yang dilakukan pada bentuk awal desain adalah teknik connectivity. Teknik menghubungkan dilakukan pada tiap lekukan pada satu bidang desain sehingga menghasilkan ruang spasial diantara tiap lekukan tersebut.

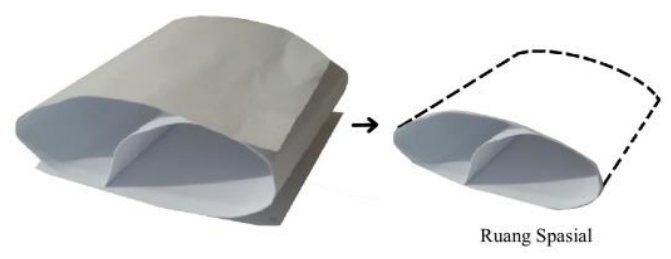

Gambar 9. Transisi Ketiga pada Zhejiang Huanglong Aquatics Center (Sumber: analisis, 2020)

\section{Transisi Keempat (Prototipe Arsitektur)}

Dapat dilihat pada Gambar 10 di bawah, wujud yang didapat dari transisi sebelumnya pada transisi keempat ini adalah potongan dari desain bangunan. Dari terbentuknya ruang spasial di transisi ketiga, dapat terlihat bentuk bangunan hingga dapat dikembangkan menjadi wujud digital berupa gambar potongan. Gambar potongan di atas dapat memperlihatkan rencana struktur secara kasar. Dari gambar potongan kasar tersebut, rencana desain dapat dikembangkan menurut ukuran dan material yang direncanakan.
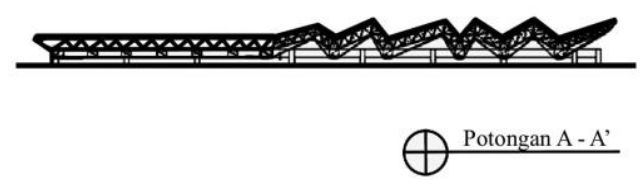

Gambar 10. Transisi Keempat pada Stadion Akuatik Gbk (Sumber: analisis, 2020)

Pada Gambar 11 dapat dilihat dua wujud digital yang didapat dari bentuk ruang spasial sebagai transisi keempat dari bangunan stadion akuatik di London ini. Kedua wujud digital tersebut berupa gambar potongan kasar dari bentuk ruang spasial. Wujud digital ini dapat memperlihatkan perkiraan awal presisi ukuran dan rencana struktur untuk rencana desain bangunan. 


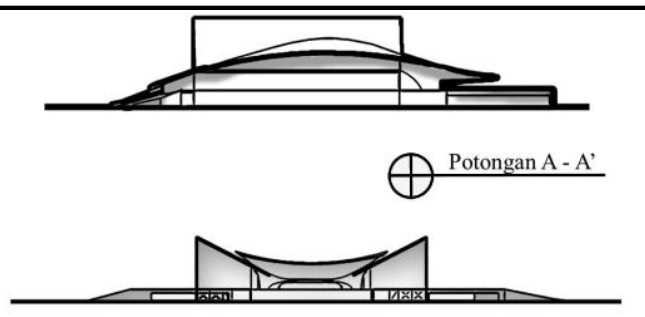

$\bigoplus$ Potongan B - B'

Gambar 11. Transisi Keempat pada London Aquatic Center (Sumber: analisis, 2020)

Transisi keempat pada bangunan Zhejiang Huanglong Aquatics Center terlihat di Gambar 12 di bawah ini. Wujud digital yang didapatkan dari transisi keempat di bentuk bangunan ini juga berupa gambar potongan. Dengan memperlihatkan kesinambungan antara bentuk awal, ruang spasial hingga struktural bangunan dalam satu gambar dari kedua sisi. Dapat dilihat pada gambar potongan dari sisi bangunan terpanjang dengan rencana dari struktur atap yang digunakan. Dapat juga dilihat pada gambar potongan dari sisi terpendek bangunan, rencana ruang dalam dari bentuk bangunan yang didapat.

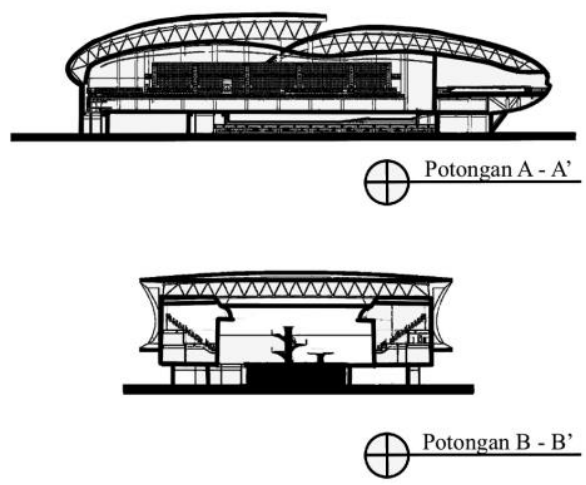

Gambar 12. Transisi Keempat pada Zhejiang Huanglong Aquatics Center (Sumber: analisis, 2020)

\section{Kesimpulan}

Arsitektur folding merupakan teknik pencarian bentuk yang menggunakan kertas sebagai medianya. Lalu media tersebut diberikan perlakuan atau aksi dan menjadikan sebuah kertas tersebut bervolume hingga membentuk ruang. Konsep arsitektur folding dapat diterapkan pada rancangan desain bangunan dengan menerapkan 4 transisi, seperti yang dijelaskan Sophia Vyzovity. Keempat transisi tersebut yaitu, Transisi Pertama (Materi dan Fungsi), Transisi Kedua (Algoritma), Transisi Ketiga (Spasial, Struktural dan Organisasional) dan Transisi Keempat (Prototipe Arsitektur).

Transisi pertama (materi dan fungsi) yang merupakan sebuah eksplorasi bentuk yang dilakukan pada kertas guna mencari bentuk-bentuk baru yang berelasi dengan fungsi rancangan. Transisi kedua merupakan sebuah algoritma dari aksi atau langkah yang dilakukan dalam eksplorasi bentuk, yang dituangkan dengan bentuk pemetaan. Transisi ketiga merupakan bentuk pemahaman baik ruang spasial, struktural maupun organisasi yang dihasilkan dari bentuk yang didapat. Transisi keempat menjadi luaran dari keseluruhan transisi yang berupa wujud digital. Wujud digital yang dimaksud dapat berupa gambar atau sketsa kasar bahkan maket kasar dari bentuk yang didapat agar menjadi dasar dari gambar rencana desain yang akan dikembangkan.

Dari keempat transisi yang telah dianalisis pada ketiga bangunan stadion akuatik, dapat terlihat bagaimana penerapan konsep arsitektur folding pada setiap bangunannya. Dimulai dari bangunan Stadion Akuatik GBK, terlihat tidak menerapkan konsep arsitektur folding pada transisi ketiga. Hal ini dikarenakan pembentukan ruang spasial pada bangunan dibentuk bukan dari wujud eksplorasi bentuk, melainkan wujud eksplorasi bentuk hanya digunakan untuk mencari bentuk atap. Sedangkan kedua bangunan stadion akuatik lainnya menerapkan keempat transisi arsitektur folding. Dari hal ini terlihat bagaimana keunikan bentuk kedua bangunan tidak hanya terlihat dari bentuk luar bangunan saja, namun hingga ke bentuk ruang dalam bangunan. Tidak sama halnya bentuk ruang dalam bangunan Stadion Akuatik GBK, yang terlihat cukup monoton. 
Maka dari penelitian ini terlihat bagaimana konsep arsitektur folding dengan menerapkan keempat transisi ini dapat menciptakan bentuk unik dan tidak monoton. Bentuk unik ini dapat tercipta tidak hanya pada bentuk luar bangunan, namun juga pada bentuk ruang dalam bangunan bahkan hingga ke struktur bangunan. Hal inilah yang menjadikan konsep arsitektur folding sebagai jawaban dari permasalahan memperkaya dan memperluas bentuk dalam bidang arsitektur.

\section{Referensi}

Pallasmaa, J. (2018). Architecture as Experience: The Fusion of the World and the Self. Architectural Research in Finland, 2 (1), 9-17.

Hujaeri, A. (2019). Estetika Islam : Arsitektur Masjid Perspektif Seyyed Hossein Nasr. Repository UIN Jakarta , 41.

Ramli , S., \& Santosa, H. (2020). Penilaian kualitas estetika elemen arsitektural bangunan Kolonial di Jalan Basuki Rahmat, Malang . ARTEKS : Jurnal Teknik Arsitektur , 5 (1), 103.

Shen, T., \& Nagai, Y. (2017). An Overview of Folding Techniques in Architecture Design. World Journal of Engineering and Technology, 05 (03), 8.

Taliawo, P., Tarore, R., \& Rompas, L. (2018). Galeri Seni di Manado. Folding Architecture. Jurnal Arsitektur DASENG , 7 (1).

Gregory, M., Supardjo, S., \& Mandey, J. (2017, May). Gelanggan Olahraga Lohoraung Di Tagulandang Folding Architecture. Daseng : Jurnal Arsitektur, 77-86.

Torondek, V., \& Erdiono, D. (2017). Folding Arsitektur. Jurnal Media Matrasain, 14 (3), 52-60.

Mailoor, F. M., Siregar, F. O., \& Karongkong, H. (2017, May). Office Park Di Manado (Unfolding Architecture). Daseng : Jurnal Arsitektur, 181-190.

Rahman, N. (2018, Juni). Perancangan rumah tumbuh kembang anak usia dini di Kota Malang : Tema: folding architecture. Universitas Islam Negeri Maulana Malik Ibrahim .

Macarthur, K. (2019). Balancing Surface, Volume, and Materiality: Integrating Visual and Haptic Approaches into Graphic Design Processes to Enhance Audience Understanding and Emotional Response. Dialectic , 2 (2), 161-178.

Vyzovity, S. (2004). Folding Architecture. Amsterdam: The Netherlands.

Olivier, B. (2017). The ethical (and political) status of theorizing the subject: Deleuze and Guattari. Psychotherapy and Politics International, 15 (2).

Hafiludien, A., \& Istiawan, D. (2018). Penerapan Algoritma Self Organizing Maps Untuk Pemetaan Penyandang Kesejahteraan Sosial (PMKS) di Provinsi Jawa Tengah Tahun 2016. The 7th University Research Colloqium 2018 STIKES PKU Muhammadiyah Surakarta, 4.

Aisy, K., \& Anisa. (2020). Kajian Tipologi Bangunan pada Pusat Rehabilitasi Mental Disorder. MARKA (Media Arsitektur dan Kota) : Jurnal Ilmiah Penelitian , 3 (2), 55.

Fauri, M. (2018, Januari 18). "Prototipe dalam Arsitektur" Kajian Kritik Normatif Pada Perancangan Desain Prototipe dan Perannya Sebagai Pembentuk Identitas Wilayah / Daerah. Retrieved Januari 20, 2021, from Universitas Islam Indonesia: https://dspace.uii.ac.id/handle/123456789/6151

Dewi, H., \& Hayyun, M. (2018). Alternatif Metode Kreatif untuk Pembelajaran Disain Arsitektur Menghadapi Era 4.0. IKRA-ITH HUMANIORA : Jurnal Sosial dan Humaniora , 2 (3), 11.

Muhajjalin, M., \& Satwikasari , A. (2020). Kajian Penerapan Konsep Arsitektur Hijau Pada Bangunan Museum Geologi Studi Kasus : Museum Fossa Magna Jepang. Jurnal Arsitektur PURWARUPA , 04 (1), 26. 